\title{
Surface energy balance of seasonal snow cover for snow-melt estimation in N-W Himalaya
}

\author{
Prem Datt*, P K Srivastava, P S Negi and P K Satyawali \\ Snow and Avalanche Study Establishment (SASE), Research $\&$ Development Centre, Chandigarh, India. \\ *e-mail: datt_prem@rediffmail.com
}

\begin{abstract}
This study describes time series analysis of snow-melt, radiation data and energy balance for a seasonal snow cover at Dhundi field station of SASE, which lies in Pir Panjal range of the N-W Himalaya, for a winter season from 13 January to 12 April 2005. The analysis shows that mean snow surface temperature remains very close to the melting temperature of snow. It was found close to $-1^{\circ} \mathrm{C}$ for the complete observational period which makes the snow pack at Dhundi moist from its beginning. The average air temperature over this period was found to be $3.5^{\circ} \mathrm{C}$ with hourly average variation from $-5.5^{\circ} \mathrm{C}$ to $13^{\circ} \mathrm{C}$. The snow surface at this station received a mean short wave radiation of $430 \mathrm{~W} \mathrm{~m}^{-2}$, out of which $298 \mathrm{~W} \mathrm{~m}^{-2}$ was reflected back by the snow surface with mean albedo value of 0.70 . The high average temperature and more absorption of solar radiation resulted in higher thermal state of the snowpack which was further responsible for faster and higher densification of the snowpack. Net radiation energy was the major component of surface energy budget with a mean value of $83 \mathrm{~W} \mathrm{~m}^{-2}$. Bulk transfer model was used to calculate turbulent fluxes. The net energy was utilized for satisfying cold content and snow-melt by using measured snow surface temperature and density of snow pack. The mean square error between calculated and measured daily snow-melt was found to be approximately $6.6 \mathrm{~mm}$ of water equivalent.
\end{abstract}

\section{Introduction}

Seasonal snow-melt contributes substantially to rivers of north India every year during the ablation period which generally occurs from April to June. The Indian Himalaya, particularly the Pir Panjal range receives most of the precipitation in the form of snow in pre- and mid-winter and sometimes rain in the late winter due to the western disturbances from November to April each year. The seasonal snowpack grows in layered structure with each layer having different physical and mechanical characteristics. The snowpack gets stratified because of successive snow events throughout the winter season and each snow event encounters a different set of meteorological parameters at the time of its occurrence and afterward. Snow pack continuously interacts with environment and exchanges energy with atmosphere above it and the ground below. The energy exchange processes set up the temperature distribution within the snow pack which is responsible for metamorphic changes with time (Colbeck 1983). In late winter when air temperature rises, the snowpack becomes isothermal and wet. The melt water within the snow pack plays an important part for wet snow avalanche formation. Melt water produced at the surface percolates within the snowpack and may undergo the cycle of melt-freeze. The phenomenon of melt-freeze sometimes introduces the weak layers within the snowpack which may trigger the avalanches in future. Moreover, the melt water reduces the strength of snow layers significantly and poses the wet snow avalanche hazard. The net

Keywords. Surface energy balance; turbulent flux; radiation energy; snow-melt; data analysis; hydrology; modeling. 
energy available at snow surface and the thermal state of snow pack controls the amount of water generation in the snowpack.

A number of studies have been carried out in the past to understand the energy and mass balance over the snow surface. Rockwood (1964) evaluated energy exchange across air-snow interface by taking air temperature as a sole index. Anderson (1976) used energy balance method to compute the temperature profile within a snow cover. Hong et al (1992) calculated the energy balance over the snow surface for quantification of snow-melt by using bulk transfer method in the western Tien Shan Mountains, China. Very few studies have been carried out on energy balance and snowmelt for seasonal snow of the Indian Himalaya. Thapa (1980) and Bajracharya (1984), used degree day approach for snow-melt studies. Upadhyay et al (1985) have estimated snow-melt for Sutlej catchment in the Indian Himalaya. Ganju et al (1999), explains the evolution of the snow cover vis-à-vis energy balance for $\mathrm{N}-\mathrm{W}$ Indian Himalaya. Negi et al (2004) have calculated surface energy balance for a seasonal snow pack. In this study energy balance model was used for the estimation of surface snow-melt. We used the bulk transfer model for estimation of turbulent fluxes. The shortwave radiation was directly measured and longwave radiation was estimated by using algorithms from reported literature.

\section{Study site, instrumentation and data}

The station Dhundi (lat. $32^{\circ} 21^{\prime} 20^{\prime \prime}$, long. $77^{\circ} 07^{\prime} 41^{\prime \prime}, 3050 \mathrm{~m} \mathrm{msl}$ ), located in Pir Panjal of $\mathrm{N}-\mathrm{W}$ Himalaya, is surrounded on three sides by high mountains partially covered with vegetation. The tree line extends up to approximately $3500 \mathrm{~m}$. This observatory is below tree line and receives good amount of snow. This is the representative observatory of Pir Panjal range and the climatic conditions of this station had been described by Singh and Ganju (2006). Snow pack in this region can be considered relatively deep and warm, a feature of maritime snow climate. Snow meteorological data at this observatory was daily monitored at 0300 UTC and 1200 UTC from 1 November 2004 to 30 April 2005 (SASE Annual Technical Report 2004-2005). However, the energy balance and snow-melt data discussed in the present study was collected from 13 January to 12 April 2005. The radiation data, both global and reflected, was collected on hourly average basis by using pyranometers (Kipp-Zonen, Model CM 14) working in the spectral range $0.3-3.0 \mu \mathrm{m}$ with data logger CR-10X from Campbell scientific. Surface temperature of snow was measured by portable hand

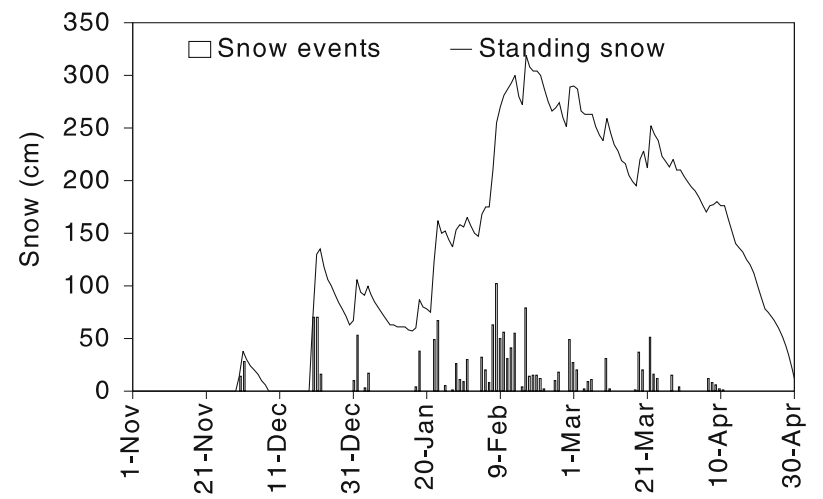

Figure 1. Standing snow and fresh snow events at Dhundi Observatory, winter 2004-2005.

held infra-red based snow thermometer (Wahl Instruments Model DHS24L). Air temperature, relative humidity, atmospheric pressure and wind speed were measured by conventional measurement instruments. The hourly cloud amount and cloud type were assessed by visual inspection every hour.

Snow cover evolution and frequency of snow events for winter 2004-2005 consisting of November, December, January, February, March and April, are illustrated in figure 1. A total of 21 snow events were received by the station during this period. The maximum amount of fresh snowfall in a single storm was $458 \mathrm{~cm}$ which continued for a period of 11 days from 3 to 13 February 2005. The station achieved maximum standing snow of season $319 \mathrm{~cm}$ on 16 February 2005 at observatory. Weather conditions that prevailed at the observatory during winter season 2004-2005 were divided into four categories, viz., clear, overcast, partly cloudy and snowy. Out of the total days $15 \%$ were clear days, $15 \%$ were overcast days and $18 \%$ were snowy days. Most of the time (52\%) partly cloudy weather was observed at this location. The overcast conditions increase as we move from November to April. The month of February experienced maximum number of snowfall days during the season.

\section{Methodology}

\subsection{Surface energy balance}

Snowpack exchanges energy with atmosphere above it and ground below. The energy exchange between snow surface and air consists of radiative fluxes and turbulent fluxes. The net energy flux at the snow surface is calculated by the following equation:

$$
\Delta Q=S_{\text {in }}+S_{\text {out }}+L_{\text {in }}+L_{\text {out }}+H_{\text {se }}+H_{\text {la }},
$$


where $\Delta Q$ is net energy at the surface and $S_{\text {in }}$, $S_{\text {out }}$ are incoming and outgoing shortwave fluxes and $L_{\mathrm{in}}, L_{\mathrm{out}}$ are incoming and outgoing longwave radiation. $H_{\mathrm{se}}$ is the sensible heat flux and $H_{\mathrm{la}}$ is the latent heat flux. Heat flux due to snowfall and rainfall on snow and ground heat flux is neglected in this study. The radiation flux which is coming towards snow surface is taken as positive and the radiation which is going away from the surface is considered negative. Snow surface also exchanges longwave energy flux with atmosphere. The longwave energy flux $\left(L_{\text {out }}\right)$ emitted by the surface is calculated by using Stephan's law as

$$
L_{\mathrm{out}}=\varepsilon_{s} \sigma T_{s}^{4},
$$

where $\varepsilon_{s}$ is the emissivity of the snow surface which is close to unity, $\sigma$ is the Stefan Boltzmann constant and $T_{s}$ is the snow surface temperature in $K$. Incoming longwave radiation $\left(L_{\mathrm{in}}\right)$ is evaluated by using the parameterizations by Prata (1996). This model estimates the emissivity of atmosphere in terms of precipitable water. The input data used for evaluation of incoming longwave is air temperature, humidity and cloudiness of the sky.

Turbulent energy components, i.e., sensible and latent heat are evaluated by using bulk transfer approach (Deardoff 1968) given by the following equation:

$$
\begin{aligned}
& H_{\mathrm{se}}=\rho_{a} C_{a} C_{h} U_{a}\left(T_{a}-T_{s}\right), \\
& H_{\mathrm{la}}=\left(\rho_{a} L M_{v} / P_{a} M_{a}\right) C_{e} U_{a}\left\{E_{i}\left(T_{a}\right)-E_{i}\left(T_{s}\right)\right\},
\end{aligned}
$$

where $\rho_{a}$ is air density, $C_{a}$ is specific heat of air, $U_{a}$ is wind velocity above the snow surface, $L$ is latent heat of sublimation, $P_{a}$ is atmospheric pressure, $M_{v}$ is molecular weight of water vapour, $M_{a}$ is molecular weight of dry air, $E_{i}$ is saturation vapour pressure, $T_{a}$ is air temperature, $T_{s}$ is snow surface temperature, $C_{h}$ is heat transfer coefficient and $C_{e}$ is humidity transfer coefficient. The bulk transfer equations were adjusted for stability of the atmosphere using the Richardson number $\left(R_{i}\right)$ for neutral, stable and unstable atmospheric conditions (Hong et al 1992).

\subsection{Snow-melt calculation}

The amount of melt is given by the following relation:

$$
d_{m}=\frac{\Delta Q}{\left(\rho_{s} c \Delta t+L_{f} \rho_{s}\right)},
$$

where $d_{m}$ is amount of snow-melt, $\rho_{s}$ is density of snow, $L_{f}$ is latent heat of fusion, $c$ is specific heat of snow and $\Delta t$ is the temperature required to bring snow at $0^{\circ} \mathrm{C}$. Energy $\Delta Q$ was assumed to be absorbed in the top layer of thickness $d_{m}$.

\section{Results and discussion}

\subsection{Meteorological conditions}

The variation of daily mean snow-surface and air temperature is illustrated in panel (A) of figure 2 . The lowest minimum hourly surface temperature recorded was $-11^{\circ} \mathrm{C}$ in the month of January. However, the daily mean snow surface temperature varied between $-5^{\circ} \mathrm{C}$ and $0^{\circ} \mathrm{C}$ with a mean of $-1^{\circ} \mathrm{C}$ for the complete observation period. The hourly air temperature varied between $-5^{\circ} \mathrm{C}$ and $13^{\circ} \mathrm{C}$, however, the daily mean air temperature fluctuated between $-3.5^{\circ} \mathrm{C}$ and $11^{\circ} \mathrm{C}$ with a mean of $4^{\circ} \mathrm{C}$ for the observation period. The complete snow pack became isothermal after 26 February 2005.

The seasonal fluctuations in atmospheric pressure and wind speed are shown in panel (B) and panel (C) of figure 2 respectively. The pressure drops were associated with the activity of westerly disturbance and were observed during the time of bad weather or snow events (SASE Annual Technical Report 2004-05). The fluctuation of daily mean wind speed was observed larger during the initial days. However, the mean wind speed at Dhundi remained $0.7 \mathrm{~m} / \mathrm{s}$ for the complete observational period. Mean humidity and mean cloud amount were observed $65 \%$ and 5.4 octa respectively.

Daily mean variation of global radiation, reflected radiation and extra terrestrial radiation (ETR) are shown in panel (D) of figure 2 . The global radiation varies depending upon atmospheric conditions, particularly with cloud amount, cloud type and Julian day (Oerlemans 2000). The fluctuations observed in the global radiation were associated with cloudy conditions formed by both local convective activity and approaching westerly disturbances (SASE Annual Technical Report 2004-2005). The mean global and reflected radiations were found to be $430 \mathrm{~W} \mathrm{~m}^{-2}$ and $298 \mathrm{~W} \mathrm{~m}^{-2}$ respectively while the mean extra terrestrial radiation (ETR) at the top of the atmosphere was $750 \mathrm{~W} \mathrm{~m}^{-2}$ for the analysis period. The maximum value of global and reflected radiations recorded at the surface were $845 \mathrm{~W} \mathrm{~m}^{-2}$ and $551 \mathrm{~W} \mathrm{~m}^{-2}$ respectively on 28 March 2005 . The snow surface albedo was calculated by using both incoming and reflected radiation data and its variation is illustrated in panel (E) of figure 2. Daily mean albedo of the snow at Dhundi varied between 0.32 and 0.93 . Peaks in albedo curve correspond 

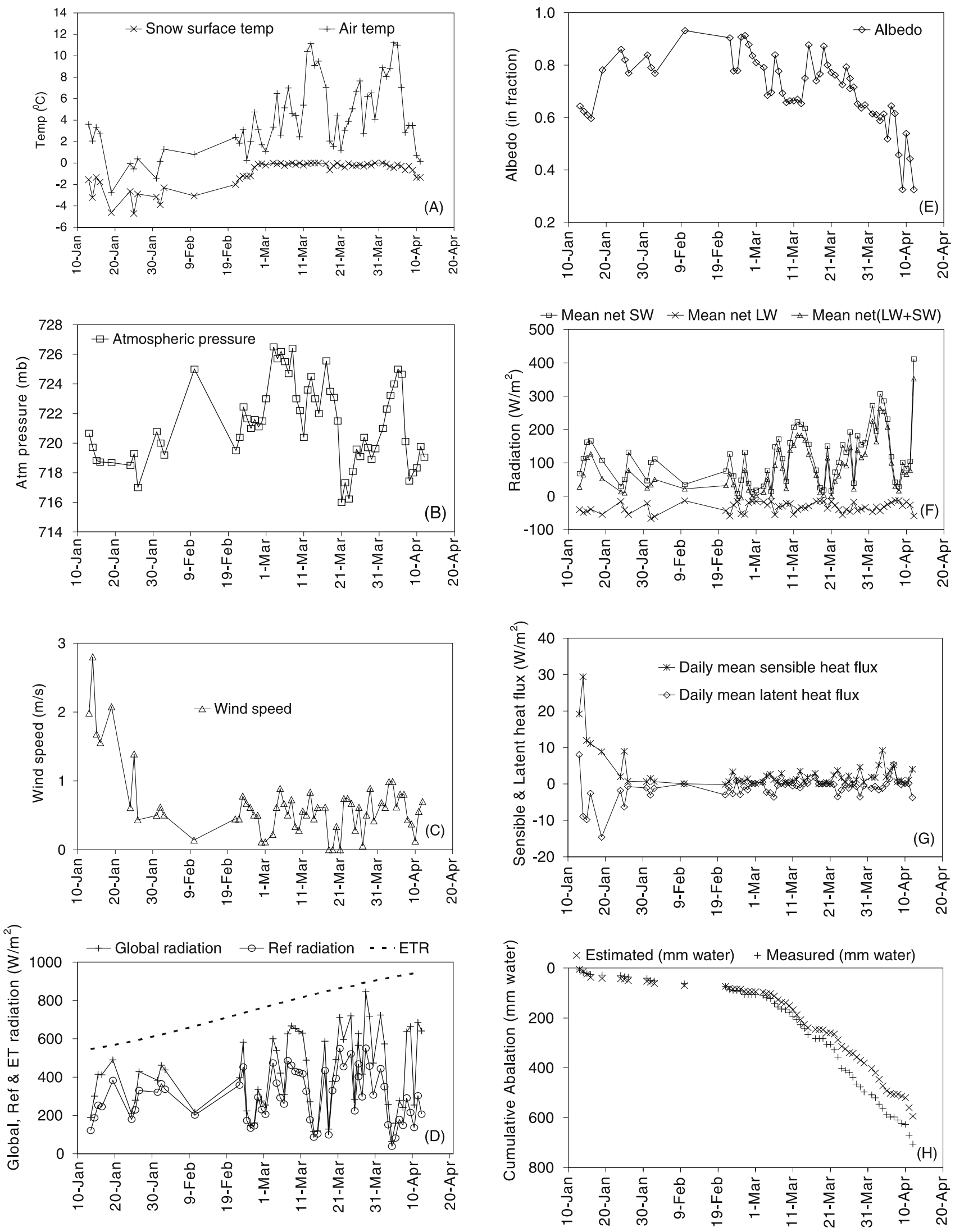

Figure 2. (A) Daily mean snow surface temperature and daily mean air temperature. (B) Daily mean atmospheric pressure. (C) Daily mean wind speed. (D) Daily mean global, reflected radiation and extra terrestrial radiation (ETR). (E) Daily mean albedo. (F) Daily mean net shortwave, net longwave and mean net radiation (net SW+ net LW) energy flux. (G) Daily mean sensible heat flux and latent heat flux. (H) Comparison of cumulative estimated snow-melt and cumulative ablation. (All parameters A-H at Dhundi for period 13 January to 12 April 2005.) 


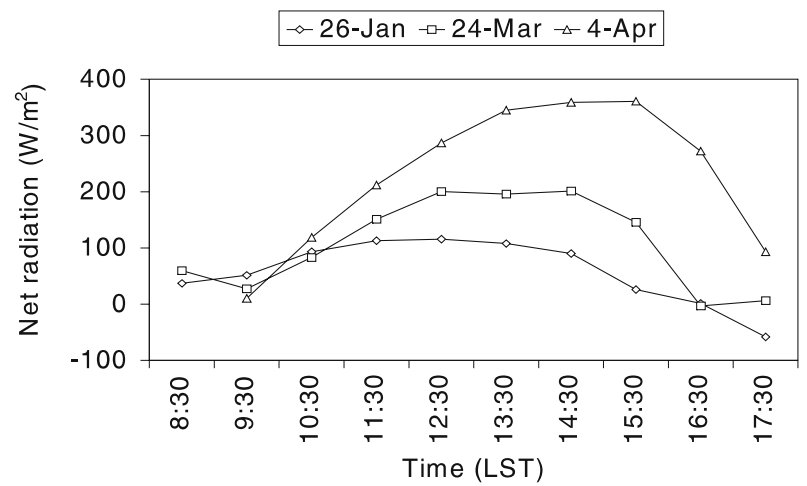

Figure 3. Variation of net radiation for three clear days of the season at Dhundi (13 January-12 April 2005).

to the fresh snow events experienced by the station. However, the albedo decreases rapidly after snow fall because of fast metamorphic changes in the snow pack caused by high air temperature conditions which prevailed at the station. It was also seen that albedo value decreases during late winter because the snow pack starts ablating and also gets contaminated. The mean albedo for the complete observation period was found to be 0.70 .

\subsection{Surface energy balance and snow-melt}

\subsubsection{Net radiation}

Daily mean net shortwave, net longwave and net radiation are illustrated in panel $(F)$ of figure 2. Maximum value of daily mean net shortwave energy flux, i.e., $411 \mathrm{~W} \mathrm{~m}^{-2}$ was recorded on 12 April 2006. The mean net shortwave energy at snow surface was $116 \mathrm{~W} \mathrm{~m}^{-2}$. The net longwave energy at the snow surface fluctuated between $-15 \mathrm{~W} \mathrm{~m}^{-2}$ and $-67 \mathrm{~W} \mathrm{~m}^{-2}$ throughout the analysis period. Depressions in the longwave energy flux curve are attributed to the clear sky condition when maximum energy is emitted by the snow surface. Mean net longwave radiation for complete observation period was $-33 \mathrm{~W} \mathrm{~m}^{-2}$. The mean net radiation energy is $83 \mathrm{~W} \mathrm{~m}^{-2}$. Diurnal variations of net radiation energy for three clear days of the season, viz., 26 January, 24 March and 4 April 2005 are compared in figure 3 . Amount of net radiation energy received by the snow surface for clear days increases significantly as season progresses towards ablation period.

\subsubsection{Turbulent heat flux}

Daily mean sensible and latent heat flux are shown in panel $(\mathrm{G})$ of figure 2. Magnitudes of sensible and latent heat energy fluxes are much smaller as compared to the radiation energy fluxes over the
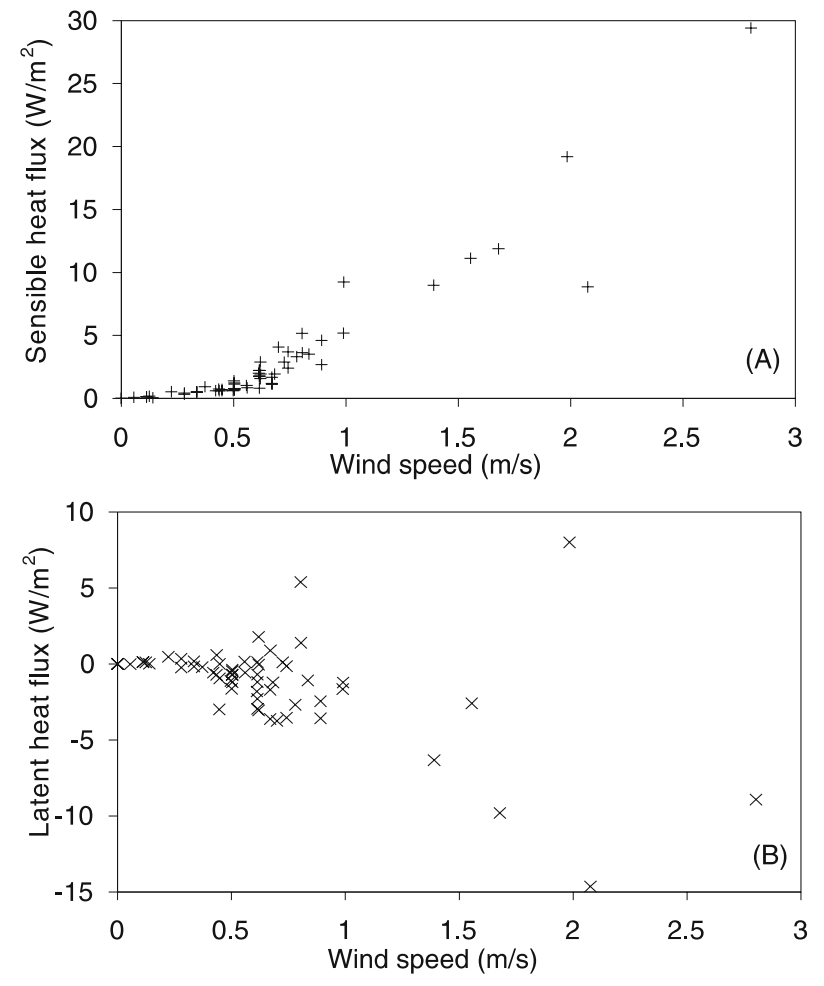

Figure 4. Variation of daily mean (A) sensible heat flux and (B) latent heat flux with wind speed at Dhundi (13 January-12 April 2005).

snowpack. Mean sensible heat flux and mean latent heat flux for the complete observation period were $2.87 \mathrm{~W} \mathrm{~m}^{-2}$ and $-1.19 \mathrm{~W} \mathrm{~m}^{-2}$ respectively. Daily mean sensible heat flux was always positive, and latent heat flux was negative most of the time except 7 April when it was $5 \mathrm{~W} \mathrm{~m}^{-2}$. The sensitivity of sensible and latent heat fluxes towards wind speed is illustrated in panel (A) and (B) of figure 4. Turbulent fluxes increase significantly with increasing wind speed.

\subsubsection{Melt estimation}

Daily snow-melt was estimated by using net energy at snow surface and density of the snow. Comparison of cumulative estimated and cumulative measured snow-melt is shown in panel $(\mathrm{H})$ of figure 2 . The cumulative calculated snow-melt is $594 \mathrm{~mm}$ of water equivalent and cumulative measured snowmelt is $706 \mathrm{~mm}$ of water equivalent. In the months of January and February very less amount of ablation was observed, however melting increases significantly from the first week of March up to the disappearing of the complete snowpack in mid April. The difference may be because of uncertainties in the measurement of parameters used to derive estimated and measured snow-melt. Snowmelt was measured by using snow stake, however due to uneven melting of snowpack around the 
stake, exact assessment of the ablation is some times difficult. During density measurement the snow sample may also face compression particularly when the snowpack is wet. In late winter when snowpack becomes shallow, soil patches appear in the snowpack which will change the effective radiation field around the observation area and may lead to some error in the estimation of net energy and snow-melt.

\section{Conclusion}

Analysis of meteorological data reveals that the snowpack at Dhundi Observatory was very close to its melting temperature during the study period. The mean snow surface temperature was $-1^{\circ} \mathrm{C}$ for the season 2004-05 which makes the snowpack moist most of the time. The high air temperature (seasons mean temperature $\sim 4^{\circ} \mathrm{C}$ ) conditions accelerate the process of rounding of the snow particles which were responsible for higher settlement and high density of the snowpack. The station received about $57 \%$ of extra terrestrial radiation at the snow surface during the study period. The radiation energy flux was the dominant source of energy at the surface of snowpack and it contributed most of the energy to the surface. The turbulent energy fluxes constitute a small fraction of total energy. The mean net energy at the surface was found to be $84.68 \mathrm{~W} \mathrm{~m}^{-2}$ for the season under study. The cumulative calculated snow-melt was $594 \mathrm{~mm}$ of water equivalent and measured snow-melt was $706 \mathrm{~mm}$ at the observatory location for the complete observational period. The daily square root mean difference between calculated and measured snow-melt was approximately $6.6 \mathrm{~mm}$ of water equivalent.

\section{Acknowledgements}

The authors gratefully acknowledge the technical help provided by Vinod Kumar STA 'B' and Praveen Kumar STA 'B' for data collection at field research station. This work was supported by the Defence Research Development Organization (Project No. RD - PI-2004/SAS-35).

\section{Notations}

$\Delta Q \quad$ Net energy at the surface $\left(\mathrm{W} \mathrm{m}^{-2}\right)$

$S_{\text {in }} \quad$ Incoming shortwave radiation $\left(\mathrm{W} \mathrm{m}^{-2}\right)$

$S_{\text {out }}$ Outgoing fluxes of shortwave $\left(\mathrm{W} \mathrm{m}^{-2}\right)$

$L_{\text {in }} \quad$ Incoming longwave radiation $\left(\mathrm{W} \mathrm{m}^{-2}\right)$
$L_{\text {out }} \quad$ Outgoing longwave radiation $\left(\mathrm{W} \mathrm{m}^{-2}\right)$

$H_{\text {se }} \quad$ Sensible heat flux $\left(\mathrm{W} \mathrm{m}^{-2}\right)$

$H_{\text {la }} \quad$ Latent heat flux $\left(\mathrm{W} \mathrm{m}^{-2}\right)$

$\varepsilon_{s} \quad$ Emissivity of the snow surface (0.97)

$\sigma \quad$ Stefan Boltzmann constant $(5.67 \times$ $10^{-8} \mathrm{~W} \mathrm{~m}^{-2} \mathrm{~K}^{-1}$ )

$T_{a} \quad$ Air temperature $\left({ }^{\circ} \mathrm{C}\right)$

$T_{s} \quad$ Snow surface temperature $\left({ }^{\circ} \mathrm{C}\right)$

$\rho_{a} \quad$ Air density $\left(1.2922 \mathrm{~kg} \mathrm{~m}^{-3}\right.$ at standard temperature and pressure)

$\rho_{s} \quad$ Density of snow $\left(\mathrm{kg} \mathrm{m}^{-3}\right)$

$U_{a} \quad$ Wind velocity $(\mathrm{m} / \mathrm{s})$

$L$ Latent heat of sublimation $(2.834 \times$ $10^{6} \mathrm{~J} \mathrm{~kg}^{-1}$ at $273.15 \mathrm{~K}$ )

$L_{f} \quad$ Latent heat of fusion $\left(3.335 \times 10^{5} \mathrm{~J} \mathrm{~kg}^{-1}\right)$

$P_{a} \quad$ Atmospheric pressure (mb)

$M_{v} \quad$ Molecular weight of water vapour $\left(18.015 \times 10^{-3} \mathrm{~kg} \mathrm{~mol}^{-1}\right)$

$M_{a} \quad$ Molecular weight of dry air $(28.96 \times$ $10^{-3} \mathrm{~kg} \mathrm{~mol}{ }^{-1}$ )

$E_{i} \quad$ Saturation vapour pressure $(\mathrm{mb})$

$R_{i} \quad$ Richardson number ( $=0$ for neutral and $<0$ for unstable, $>0$ for stable)

$C_{h}$ Heat transfer coefficient $\left(1.0 \times 10^{-4}-\right.$ $1.08 \times 10^{-2}$ )

$C_{e} \quad$ Humidity transfer coefficient $\left(1.0 \times 10^{-4}-\right.$ $1.08 \times 10^{-2}$ )

$d_{m} \quad$ Amount of snow-melt ( $\mathrm{mm}$ of water/day)

$c \quad$ Specific heat of snow $(2.211 \times$ $10^{3} \mathrm{~J} \mathrm{~kg}^{-1} \mathrm{~K}^{-1}$ )

$C_{a} \quad$ Specific heat of air $(1.006 \times$ $10^{3} \mathrm{~J} \mathrm{~kg}^{-1} \mathrm{~K}^{-1}$ )

\section{References}

Anderson E A 1976 A point energy and mass balance model of a snow cover; A Technical Report NWS 19, National Oceanic and Atmospheric Administration (NOAA), USA.

Bajracharya A 1984 A study of snow-melt runoff process, ME Dissertation, University of Roorkee, Roorke, India.

Colbeck S C 1983 Theory of metamorphism of dry snow; J. Geophys. Res. 88 5475-5482.

Deardroff J W 1968 Dependence of air sea transfer coefficients on bulk stability; J. Geophys. Res. 73(8) 25492557.

Ganju A, Satywali P K, Singh A and Sethi D N 1999 Snow Cover Simulation Model - A Review; Defence Science Journal 49(5) 419-436.

Hong M, Zongchao L and Yifeng L 1992 Energy balance of snow cover and simulation of snow-melt in the western Tien Shan mountains, China; Ann. Glaciol. 16 73-78.

Negi P S, Semwal G, Sethi D N and Chand U 2004 A comparative study of snow-met parameters, albedo and estimated surface energy budget of snow surface of Pir Panjal 
and Great Himalayan ranges of Indian Himalaya, International Symposium on Snow Monitoring and Avalanches $567-571$.

Oerlemans J 2000 Analysis of a 3-year meteorological record from the ablation zone of Morteratschgletscher, Switzerland: energy and mass balance; J. Glaciol. 46155.

Prata 1996 A new longwave formula for estimating downward clear-sky radiation at the surface; Quart. J. Roy. Meteor. Soc. 122 1127-1151.

Rockwood D M 1964 Stream flow synthesis and reservoir regulation; Technical Bulletin 22, U.S. Army Engineer Division, North Pacific, Portland, Oregon.
SASE Annual Technical Report, 2004-05.

Singh D and Ganju A 2006 Improvement in nearest neighbor weather forecast model performance while considering the previous days forecast for drawing forecast for the following day; Curr. Sci. 91(12) 1686-1691.

Thapa K B 1980 Analysis for snow-melt runoff during premonsoon months in Beas basin using satellite imageries; $M E$ Dissertation, University of Roorkee, Roorkee, India.

Upadhayay D S, Rajnikant, Chowdhury J N and Katyal K N 1985 Some characteristics of snow cover in upper Beas Catchment; Mausam 36(2) 215-220. 